\title{
POLISH STEREOLOGY - A HISTORICAL REVIEW
}

\author{
ANETA GĄDEK-MOSZCZAK, PIOTR MATUSIEWICZ
}

Cracow University of Technology, Department of Mechanical Engineering, Institute of Applied Informatics, 37 Jana Pawła II Av., 31-864 Kraków, Poland, gadek@mech.pk.edu.pl; AGH University of Science and Technology, Faculty of Metals Engineering and Industrial Computer Science, 30-059 Kraków, 30 Mickiewicza av., Poland e-mail: matus@agh.edu.pl

(Received July 13, 2017; revised October 20, 2017; accepted October 23, 2017)

\begin{abstract}
In the paper, the authors present the history of stereology development in Poland from the 1930s until now. The authors concentrate on the talented scholars whose hard work, dedication, and enthusiasm contributed to popularizing stereological methods of quantitative assessment. From Hugo Steinhaus to now, the evolution and increase in popularity of stereology is briefly shown. The most significant achievements are described in more detail.
\end{abstract}

Keywords: quantitative metallography, historical survey, polish stereologists, stereology

\section{INTRODUCTION}

The historical survey contains dates, facts, and descriptions of the most important achievements. However, in this paper, the authors would like to concentrate on the people whose hard work, dedication, and enthusiasm contributed to popularizing stereological methods of quantitative assessment. In this article, we would like to focus not on the institutions, but the people; the individuals who have made it possible to create the Polish school of stereology. We would like to present briefly its characters and achievements and attempt to show their impact on the Polish scientific community. Next year, in 2018, we will celebrate the 30th anniversary of the Polish Society of Sterology foundation. Thus, it is an excellent opportunity to recall the most important achieves of Polish stereologists and history of the Polish Society for Stereology.

\section{FIRST STEPS IN STEREOLOGY AND QUANTITATIVE ASSESSMENT OF METAL MICROSTRUCTURE \\ HUGO STEINHAUS}

The first significant contribution to stereology in Poland was made by Hugo Steinhaus (Fig. 1), a distinguished mathematician and educator who obtained his Phd under Gilbert Hilbert at Göttingen University in 1911 and became a professor at Jan Kasimir University of Lvov (Bodziony and Hübner, 1987, Steinhaus, 1973). In Lvov, he helped to establish the famous Lvov School of Mathematics with the mathe- maticians Stefan Banach, Stanisław Ulam, Stanisław Mazur, Mark Kac, Władysław Orlicz and others.

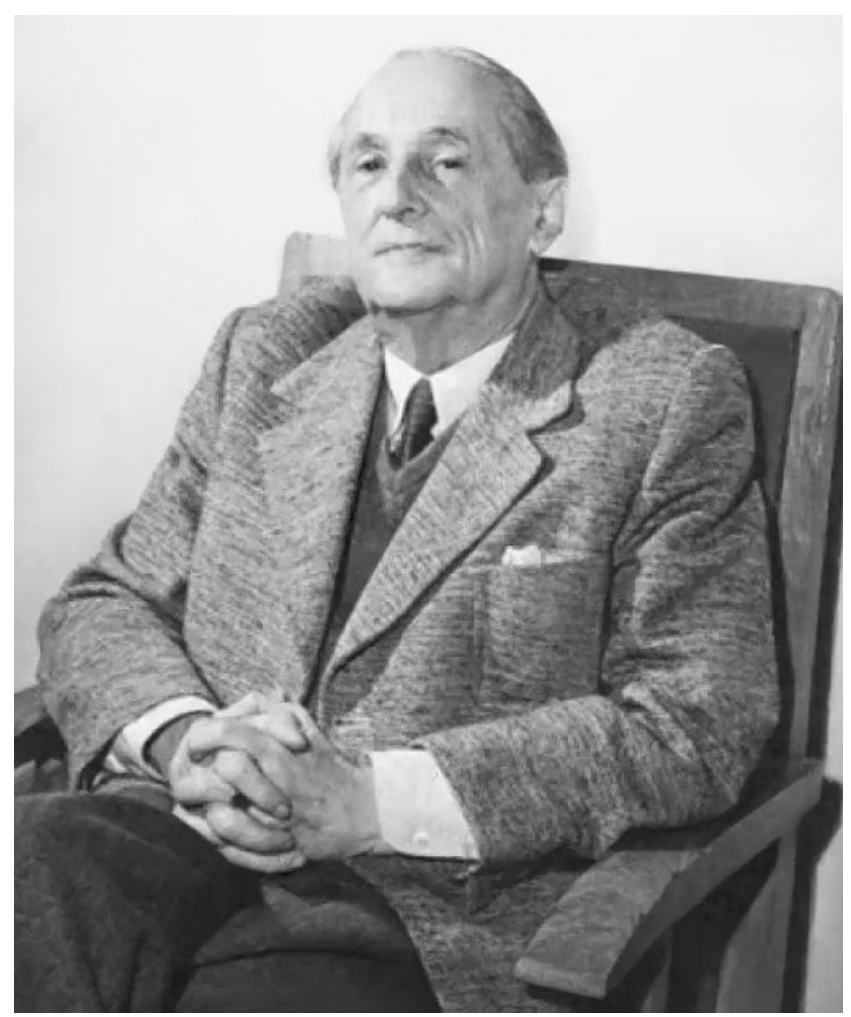

Fig. 1. Professor Hugo Steinhaus (http://math.uni.wroc.pl/ s266522/steinhaus.html).

In those days, this group of scientists was an extraordinary team of extremely talented individualists creating modern functional analysis. Their legendary meetings in the Scottish Café resulted, during endless 
mathematics discussions, in the famous Scottish Book, a notebook in which both solved and unsolved problems in the field of functional analysis and topology were noted. Steinhaus made a significant contribution in many branches of mathematics: functional analysis, geometry, mathematical logic, and game theory. He was also a pioneer of stereology when it had not yet arisen as a branch of science (Kac, 1974).

In 1930, he published the paper Zur Praxis der Rektifikation und zum Langenbegriff (Fig. 2) (Steinhaus, 1930), in which he proposed a method for measuring the length of a curve. In his method, Steinhaus approximated the length of the line by means of a square grid of size $d$, drawn on a transparent sheet, which was used as an aid to measure the length. Measurements had to be carried out a couple of times for each image of the curve by rotating the square grid to different angles as this gives results that are more accurate.

In this method he generalized the Crofton formula (Bodziony and Hübner, 1987):

$$
L=\frac{\pi}{2} \cdot \frac{1}{\pi} \int_{0}^{\pi} W(\alpha) d \alpha=\frac{1}{2} \int_{0}^{\pi} W(\alpha) d \alpha,
$$

where, $L-$ the length of the arc of plane curve is equal to $\pi / 2$.

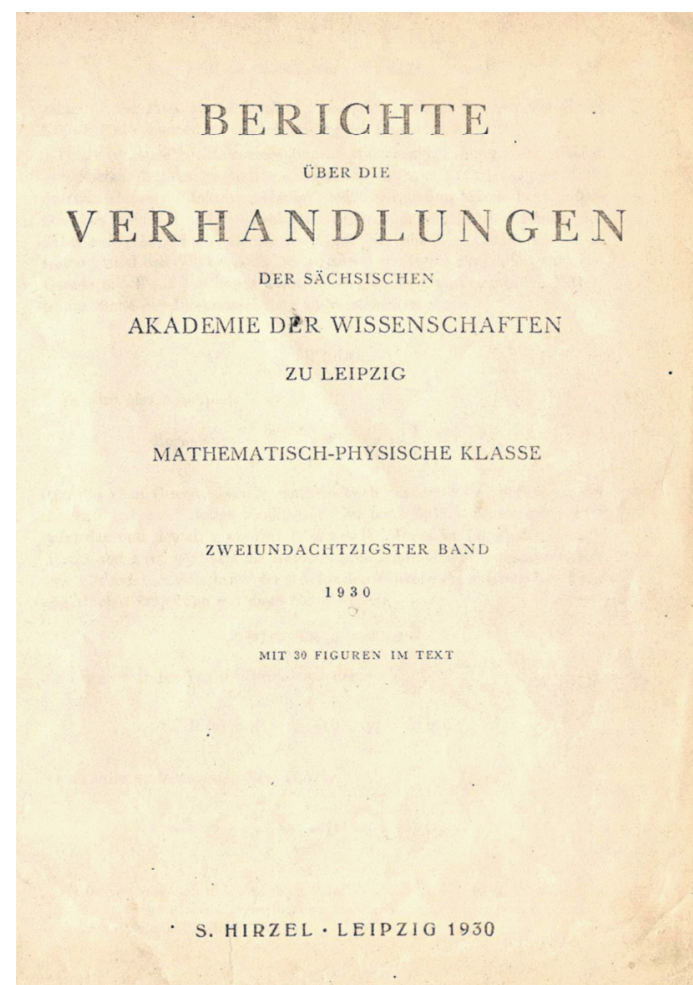

He proposed estimation of the length of the curve by applying trigonometric method. He considered $n$ directions disposed uniformly at $2 \pi / n$ intervals and obtained:

$$
L=\frac{\pi}{2 n} \sum W_{i},
$$

Final version of line length measurement proposed by Steinhaus started from representation of the Crofton formula in the following manner:

$$
A=\frac{1}{2} \sum_{k-1}^{\infty} k\left(A_{k}\right)
$$

where $A_{k}$ is a measure of set of straight lines $L$ intersecting $A$ exactly in $k$ points.

As he wrote, the idea of solving the line length measuring problem came to him when his daughter was told to measure the length of the Vistula on a map (Steinhaus, 1973). Measurement of the contours of leaves or perimeters of plane sections of trees revealed another problem: the results depend on the precision of the instrument employed. He published his method in a periodical for geographic teachers and cartographers attaching a transparent sheet of three grids turned against each other by $30^{\circ}$, consisting of lines spaced equal distance $3.82 \mathrm{~mm}$.

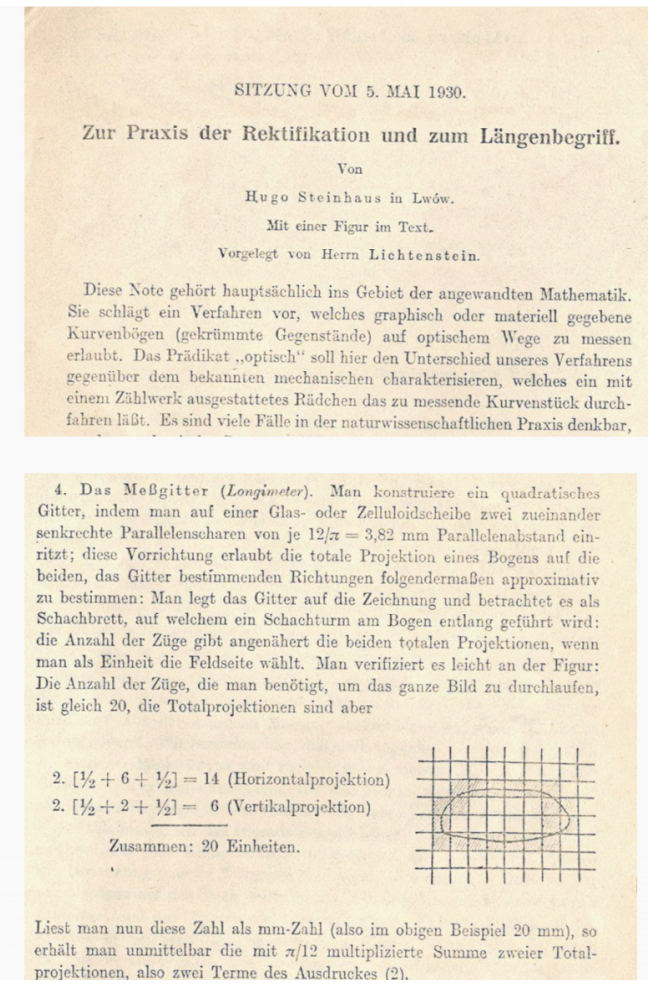

Fig. 2. Copy of Hugo Steinhaus's Zur Praxis der Rektifikation und zum Langenbegriff (Steinhaus, 1930). 
This tool was developed originally by Steinhaus and called longimeter. The curve length was assessed by counting the total number of crossing the curve with grid lines. (Steinhaus, 1932). Steinhaus also developed a geographers' method of quantitative characterization of the surface configuration of a territory. He proposed determining two parameters: average steepness (Steinhaus, 1947b) and the index of the vertical configuration (Steinhaus, 1947a) and restricted them to the utilization of information given on or obtainable from maps. His scientific activity involved applied mathematics and resulted in cooperation in other scientific fields like medicine. He developed a method for spatial localization of foreign bodies using X-ray images, which facilitated the removal of bullets from soldiers wounded during the war (Steinhaus, 1938).

The golden times for Polish mathematicians were ended by the World War II, during which many talented people died. Steinhaus luckily survived the war, despite many adversities, such as the need to hide from the Nazis because of his Jewish origin. After the end of the war, Steinhaus moved to Wroclaw, where was involved in establishing a new university. He attempted to recreate the atmosphere of Polish mathematicians before the war; however, without Banach, Ulam, and many other unusual characters, it was no longer possible. He returned to scientific and teaching activities at the University of Wroclaw. He died in 1972 in Wroclaw.

\section{JAN CZOCHRALSKI}

At the same time, another outstanding Polish scientist, chemist, and metallurgist, Jan Czochralski (Fig. 3), developed the first method for quantitative description of material microstructure. He is well known all over the world for inventing in 1916 a method of growing crystals which is now used to obtain single crystals of semiconductors: the Czochralski Growth Process. For the first time on a production scale single silicon crystals were grown using the Czochralski method in 1951 and this method is still used for industrial production of silicon for electronics, thus emphasizing the importance of Czochralski's discovery. Almost all semiconductor devices are made of monocrystalline silicon, the method of producing the wafers from which the chips are cut is crucial due to the demand for high purity. The history of prof. Jan Czochralski shows him as a tragic character. He was born in Kcynia, in the Prussian Province of Pomerania. He was educated at Charlottenburg Polytechnic in Berlin, where he specialized in metal chemistry. From the beginning, his scientific interests were related to materials for electronics; in his early publications, he dealt with the possibilities of using aluminium for electronics.

His other very important achievement was the development and patenting in 1924 of Metal B, a tin-free bearing alloy for railways that revolutionized them by increasing the speed and reliability of trains. On the request of Polish President Ignacy Mościcki, he decided to come back to Poland in 1928 and create the Institute of Foundry and Material Science. World War II interrupted his scientific work: after the war, he was arrested and accused of colluding with the German fascists during the war and although he was cleared of the charges, he was excluded from the scientific community and never returned to the Warsaw University of Technology. He died forgotten and rejected in 1953. He did not live up to the moment when the first transistor was produced using his monocrystalline growth method.

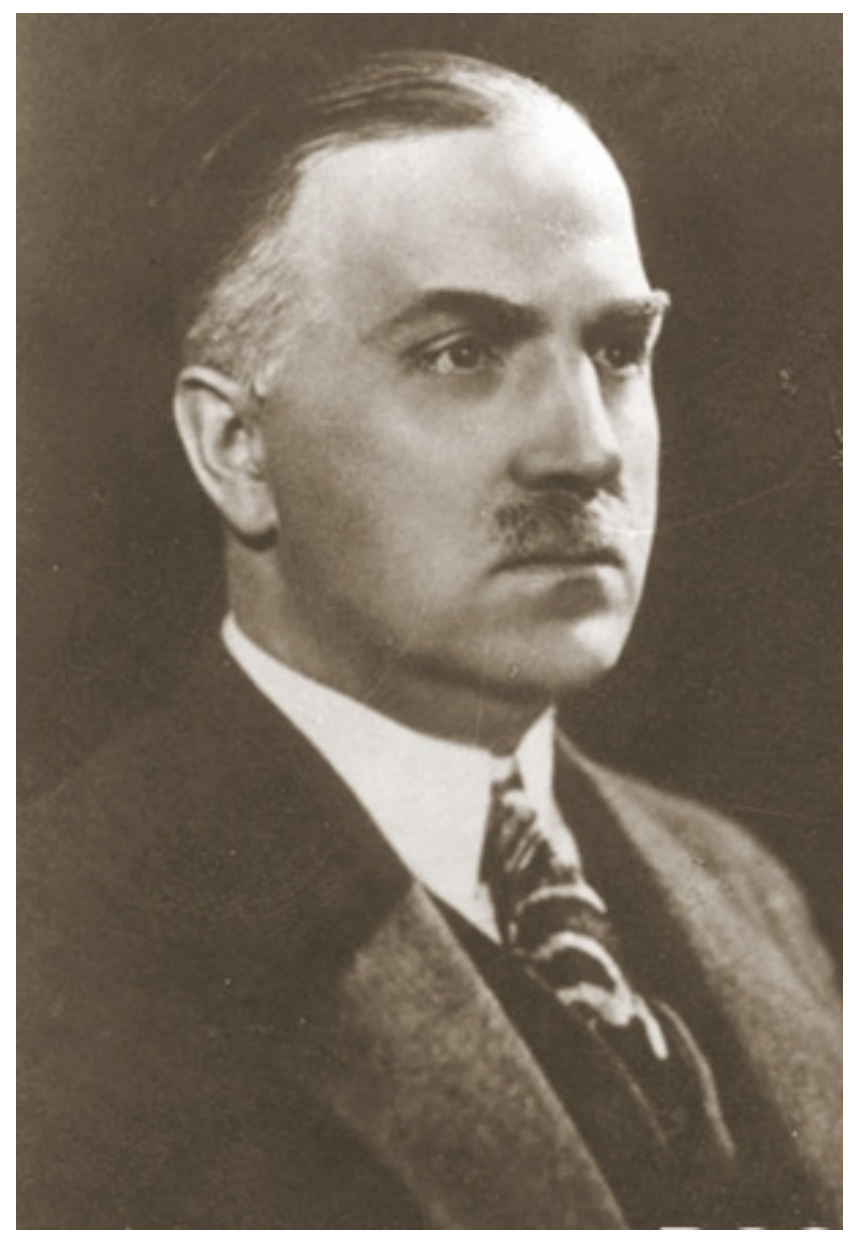

Fig. 3. Jan Czochralski, Wikipedia.

He was an author of 170 articles and is now one of the most cited Polish scientists. In 2011, he was rehabilitated and the memory of him and his great achievements restored. 
Much less is known about the achievements of prof. Czochralski that were closely related to his material studies, but his contribution to quantitative assessment of metal microstructure was very interesting. He developed a method of quantitative determination of non-metallic inclusions (Czochralski, 1935, Czochralski and Sznuk, 1936). He defined the standards for his method that were addressed to production engineers for quality control applications. He recommended:

- analysing microsections at the same microscopic magnification (100x),

- analysing anisotropic material after plastic working in two intersections: perpendicular and parallel to the direction of the plastic working,

- taking samples from ingots and castings from the inside and the outside of the object,

- microsections should be $2 \times 2 \mathrm{~cm}$ in size. The measurement should be made in a field with 0.75 $\mathrm{mm}$ size in the centre of the microsection,

- non-metallic inclusions should be divided into spheroidal inclusions $\left(\frac{\text { lenght }}{\text { width }} \approx 1\right)$, flake $\left(1<\frac{\text { lenght }}{\text { width }}<2\right)$, lamellar $\left(\frac{\text { lenght }}{\text { width }}>2\right)$,

- $1 \mathrm{~mm}^{2}$ should be regarded as an inclusion unit.

He proposed describing non-metallic inclusions by a set of 3 numbers: the number of inclusions per area unit, the mean length of inclusions measured in a longitudinal microsection, and the total surface area of inclusions in an analysed field of view. He proposed to approximate the area of individual inclusions by the use of the area of a circumscribed rectangle.

This method was recommended by Czochralski for application as a quality control device for steelmakers. It is really interesting to notice that the above described recommendation in fact describe the basic components of contemporary good metallographic practice.

\section{MICHAŁ ŚMIAŁOWSKI}

Attempts to solve the problem of quantitative description of non-metallic inclusions and their distribution in materials were also the research topic of Michał Śmiałowski, who was doctoral student of prof. Czochralski. In 1936, Michał Śmiałowski presented (Śmiałowski, 1936) and described a photometric device for automatic quantitative characterization of non-metallic inclusions and other steel microstructure components by reflecting a light beam at different angles. Śmiałowski's device can be considered a prototype micrometer or automated linear integrator for linear analysis of microstructures. The result of the analysis was the number of crystals encountered, the mean linear length of crystals, and the ratio of total crystal area to the analysed area of the sample. This microphotometer consisted of an incandescent lamp with a tungsten strip, light microscope, camera, a photoelectric cell, and an electric motor driving the tooling that automatically moved the microscope table with the probe on it during tests (Fig. 4).

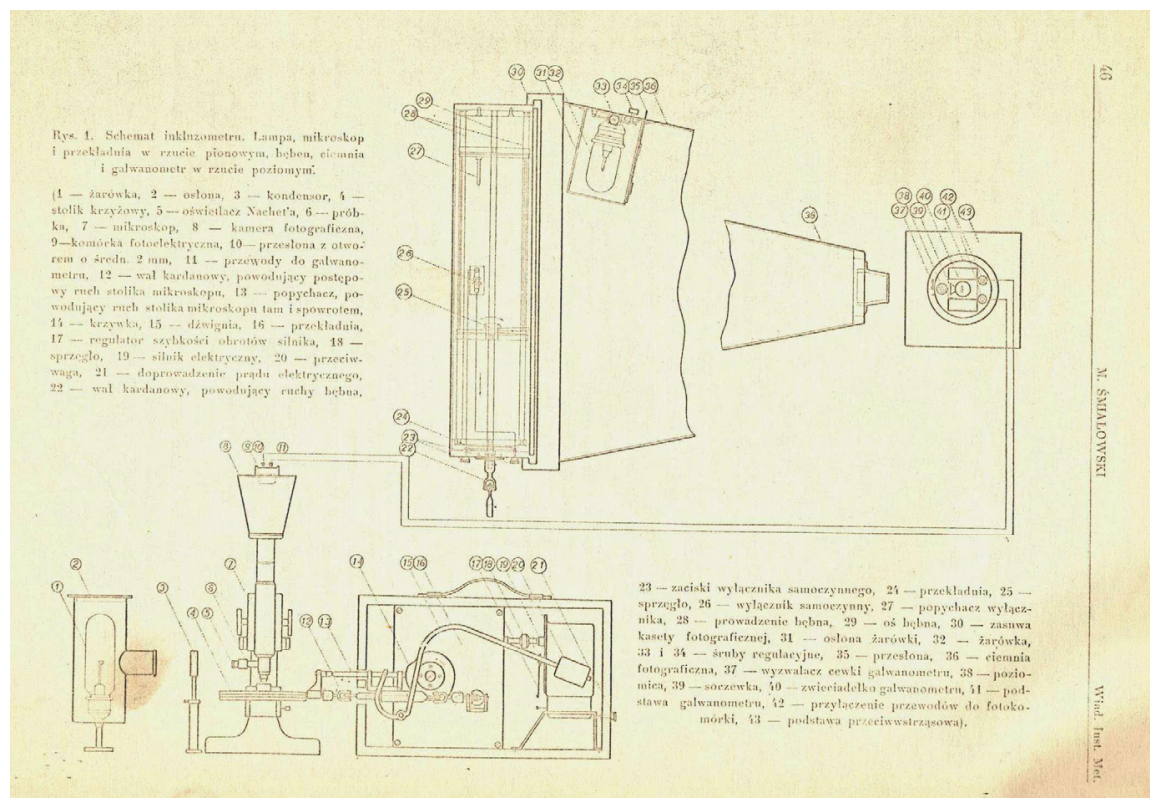

Fig. 4. Diagram of the microphotometer (Śmiatowski, 1936). 
The lamp threw a strong beam of light onto the polished surface of a sample through the capacitor and illuminator. The microscope reflected light onto the upper wall of the box and onto the active surface of the photoelectric cell, which had diaphragm of 2 $\mathrm{mm}$ and was connected to a mirror galvanometer. Changes in light intensity reflected from the sample's surface caused deviation of the mirror position. A light beam delivered a sharp spot on the bromide paper after passing through the aperture hole and galvanometer lens. If the tested sample had a smooth surface that was free of anisotropy, the obtained chart was formed as a series of straight parallel lines. If the tested surface had inclusions, scratches, or pores that were clearly visible against the background of the structure, diverging lines appeared on the chart (Fig. 5). Charts created by photometers of metallographic section make it possible to assess quantity, linear dimension, and fracture for metal components with different levels of light reflecting ability. An example result of an analysis is presented in Fig. 6.

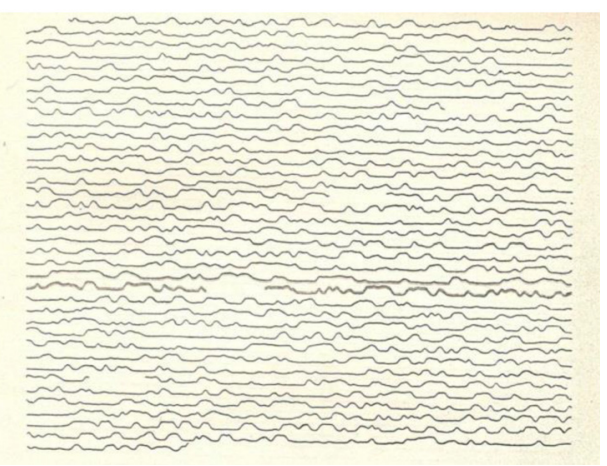

Fig. 5. Plot obtained by photometric test of annealed carbon steel $\left(0.3 \% \mathrm{C}\right.$, etched $2 \%$ alcohol $\mathrm{HNO}_{3}(x 0.5)$ (Śmiałowski, 1936).

\section{POLISCH PETROGRAPHERS: MARIA TURNAU-MORAWSKA AND JULIAN TOKARSKI}

Recalling the achievements of Polish scientists in the development and application of stereology cannot omit the achievements of Polish geologist and petrographer, Professor Maria Turnau-Morawska, who contributed to applying quantitative methods to the description of rock structure (Bodziony, 1993, Ratajczak, 2005). In the 1930s, she carried out petrographic research on the core of the crystalline Tatra Mountains. This resulted in revealing the regularity between the quantitative microscopic analysis of rocks and their chemical composition. She proposed a method of analysis including the number of analysed samples (3) and the number of counts required to assess with high probability the chemical composition of the tested rocks (100 counts). Maria Turnau-Morawska published the results of her study in 1933; her method became known as Maria Turnau-Morawska's rule and was a standard of quantitative analysis of rocks in those days. An important limitation of the method is that it could be applied only to Tatra granite, in which mineral grains do not exceed $0.5 \mathrm{~mm}$ in diameter.

Professor Julian Tokarski was an author of the planimetric-powder method of quantitative analysis of rock structure (Ratajczak, 2005). He applied this method in numerous mineral industry technologies: for instance, for quality control of gypsum chemical composition, analysis of chemical composition of potassium salts, and chemical composition of cement. The most important solution proposed by Tokarski concerned the preparation of samples in the form of
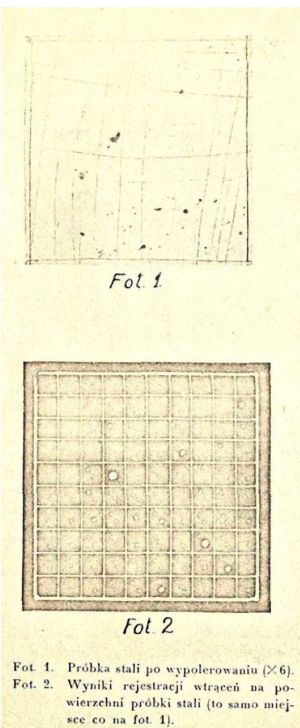
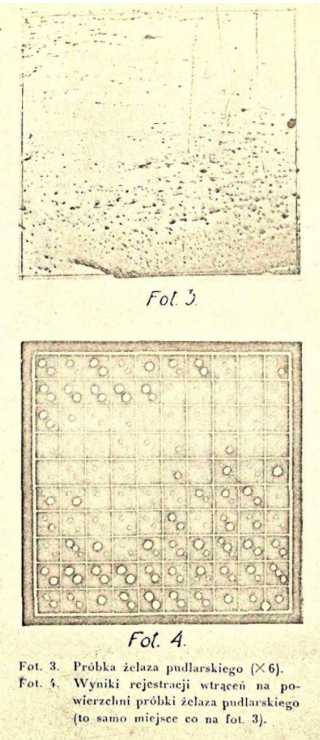

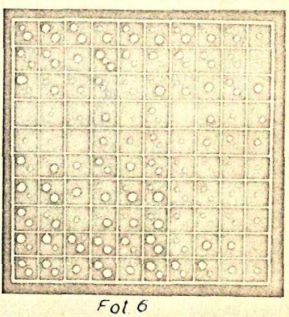

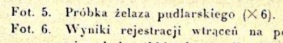

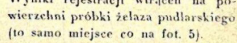

Fig. 6. Sample results of analysis carried out by (Śmiałowski, 1936). 
powder in order to avoid effects from the rock structure. He proposed the optimum number of counts in planimetric analysis of the volume of components: 300 measurement points in order to give $95 \%$ confidence of the mineral content of minerals.

This promising, dynamic development of mathematic science and its application in quantitative analysis of material structure was interrupted by World War II. Unfortunately, the Polish world of science suffered enormously during the war. At the hands of the Nazis, $30 \%$ of scholars and university lecturers were killed. After the war, Hugo Steinhaus wrote that 70 mathematicians he knew had been killed.

After the war, scientists had to rebuild the foundations of scientific centres, often in the face of the unfavourable attitudes of the communist authorities, who deeply interfered in both administrative structures and research subjects. For political reasons, some scientists were excluded from research because of their political beliefs, like Czochralski. Some scholars conducted their research work according to guidelines from the communist authorities. Limitation of scientific creativity and freedom of choice of study topics had a huge impact on scientific activity and achievements for over 4 decades.

\section{CONTEMPORARY ACHIEVEMENTS}

Revival of interest in stereological issues in Poland occurred in the 1960s as a result of geological research and the need to improve steel quality control methods. The leading role was played by the Krakow academic community, specifically Jakub Bodziony from the Strata Mechanics Research Institute of the Polish Academy of Science and Jerzy Ryś from AGH University of Science and Technology.

\section{JAKUB BODZIONY}

Professor Jakub Bodziony (Fig. 7) graduated in 1954 from AGH University of Science and Technology in Krakow, and in 1955 from the Mathematics, Physics and Chemistry Division of Jagiellonian University. During his studies, he started his work at AGH University of Science and Technology in the Department of Analytic Geometry. He cooperated with a research group dealing with the mechanics of stochastic bodies, led by Jerzy Litwiszyn and Stanisław Gołąb. His mathematics education and skills deeply influenced his further research. From the outset of his scientific career, he was deeply interested in stereological issues. As a master of mining, he worked on the description of rock structures and their properties. Because he was a mathematician, he was able to pre- cisely describe some stereological parameters of rock structure and mechanical phenomena using mathematical language.

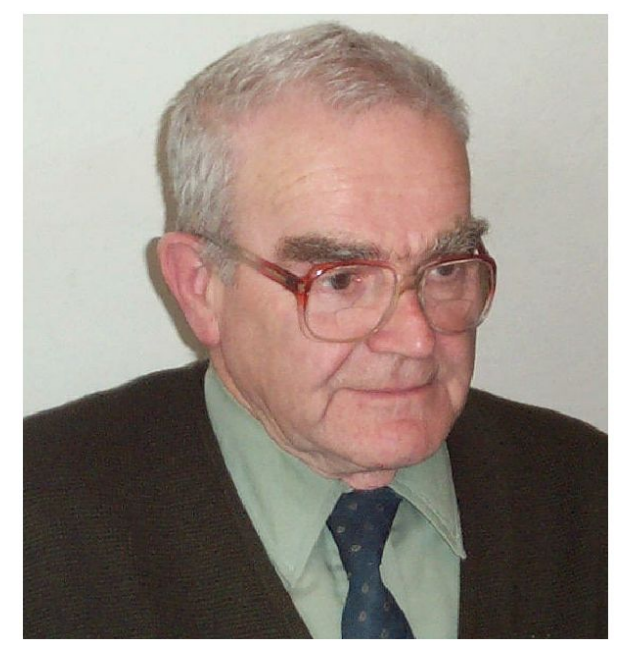

Fig. 7. Professor Jakub Bodziony.

Jakub Bodziony has considered the problem of the comminution of rock and description of the rock crushing surface. He formulated the basis for a stereological approach to calculating the division of the crushing surfaces into parts of intercrystalline and transcrystalline origin. He deals with the problem of determining the spatial indexes of rocks, considered as grain materials. His research work on stereology resulted in a uniform estimation of the basic estimators of rock minerals (volume fraction, surface area, total medium curvature, number of the spatial structure) (table. 1, (Bodziony, 1993)) (Bodziony, 1965a). He also developed a geometrical-integral model of the liberation of minerals and proposed an estimator for the assessment of $M_{V}$ (estimator for convex bodies) (Bodziony, 1965b).

$\mathrm{He}$ developed the geometric-integral model of mineral liberation based on integral geometry and Crofton's formulae. In his article Definition of particle size on the notation of total mean curvature (Bodziony, 1965b), he indicated the equivalence of Feret's diameter and the total curvature of the convex grain. An important part of his research work is devoted to formulation of the rock liberation model. Rock liberation is a side effect of rock comminution, which is important from a technical point of view. Intercrystalline comminution gives a better liberation effect. The liberation effect increases with comminution degree and is strictly related to the spatial location of the crushing surface network in the rock structure. Jakub Bodziony described this problem by applying stereological methods, presenting a formula for the relative number $N_{V}(\mathrm{~A}+\mathrm{AB})$, where $\mathrm{A}$ and $\mathrm{B}$ are 2 components of a rock (Bodziony, 1993). 


$$
N_{V}(A+A B)=N_{V}(P) \cdot V_{V}(G)+\frac{1}{4 \pi} M_{V}(P) \cdot S_{V}(G)+\frac{1}{4 \pi} S_{V}(P) \cdot M_{V}(G)+V_{V}(P) \cdot N_{V}(G),
$$

where: $N_{V}$ - number of objects per volume unit; $V_{V}$ - volume fraction of object in analyzed total volume; $S_{V}-$ surface area per volume unit, $M_{V}$ - total mean curvature; $G$ - grains, and $P$ - particles. In his liberation model, four stereological parameters were used that considered rock structure and the network of crushing surfaces.

Table 1. List of estimators of the global parameters of the structure (Bodziony, 1965a)

\begin{tabular}{|c|c|c|c|c|}
\hline Magnitude (specific) & $\begin{array}{l}\text { Mathematical } \\
\text { definition }\end{array}$ & Estimators & & \\
\hline Volume $\bar{V}$ & $\frac{\sum V_{i}}{V_{R}} \frac{\mathrm{cm}^{3}}{\mathrm{~cm}^{3}}$ & $\frac{\sum f_{i j}}{\sum f_{j}} \frac{\mathrm{cm}^{2}}{\mathrm{~cm}^{2}}$ & $\frac{\sum S_{i j}}{\sum S_{j}} \frac{c m^{1}}{c m^{1}}$ & $\frac{Z_{G}}{Z_{R}} \quad \frac{c m^{0}}{c m^{0}}$ \\
\hline Surface $\bar{S}$ & $\frac{\sum F_{i}}{V_{R}} \frac{\mathrm{cm}^{2}}{\mathrm{~cm}^{3}}$ & $\frac{4}{\pi} \frac{\sum l_{i j}}{\sum f_{j}} \frac{\mathrm{cm}^{1}}{\mathrm{~cm}}$ & $\frac{4 \sum n_{j}}{\sum S_{j}} \frac{\mathrm{cm}^{0}}{\mathrm{~cm}^{1}}$ & \\
\hline $\begin{array}{l}\text { Total medium } \\
\text { curvature } \bar{M}\end{array}$ & $\frac{\sum M_{i}}{V_{R}} \frac{\mathrm{cm}^{1}}{\mathrm{~cm}^{3}}$ & $2 \pi \frac{\sum m_{j}}{\sum f_{j}} \frac{\mathrm{cm}^{0}}{\mathrm{~cm}^{2}}$ & & \\
\hline Number $\bar{N}$ & $\frac{N}{V_{R}} \quad \frac{c m^{0}}{c m^{3}}$ & & & \\
\hline \multicolumn{5}{|c|}{$\begin{array}{l}\text { Where: } V_{\mathrm{R}}-\text { volume of analysed sample, } \mathrm{V}_{\mathrm{i}}, \mathrm{F}_{\mathrm{i}}, \mathrm{M}_{\mathrm{i}}-\text { volume, surface and total medium curvature of each particle, } \\
\text { respectively, } \\
\mathrm{f}_{\mathrm{ij}} \text { - area of the analysed cross-section of the particle; } \\
\mathrm{i}_{\mathrm{ij}} \text { - length of the perimeter of analysed cross-section of the particle; } \\
\mathrm{m}_{\mathrm{j}} \text { - number of particles crossed by the test line on analysed cross-section; } \\
\text { index } i \text { - number of analysed particle, } \\
\text { index } j \text { - number of cross-section. } \\
\sum f_{j}-\text { total area of all analysed cross-sections. } \\
\mathrm{Z}_{\mathrm{G}}-\text { number of points that hit the analysed particle, } \\
\mathrm{Z}_{\mathrm{R}}-\text { number of all points put on the analysed sections. }\end{array}$} \\
\hline
\end{tabular}

He cooperated with Władysław Kraj under the problem of description mineral liberalization. Kraj also considered the problem of discontinuities of a material. He developed a method for determination of the spatial orientation of the surface area of discontinuities in a rock based on measurements of the directions of the traces of these surfaces on flat sections differently oriented in the rock (Kraj, 1986).
At the $1^{\text {st }}$ Conference on Stereology in Material Science in 1983 (SterMat'83), Professor Bodziony noticed that due to the increasing number of people whose research activity was strongly related to stereology, a scientific society should be organized to help and consolidate scholars from many universities in Poland. This idea was realized in 1988; the first President of the Polish Society for Stereology became Jakub Bodziony. 


\section{JERZY RYŚ}

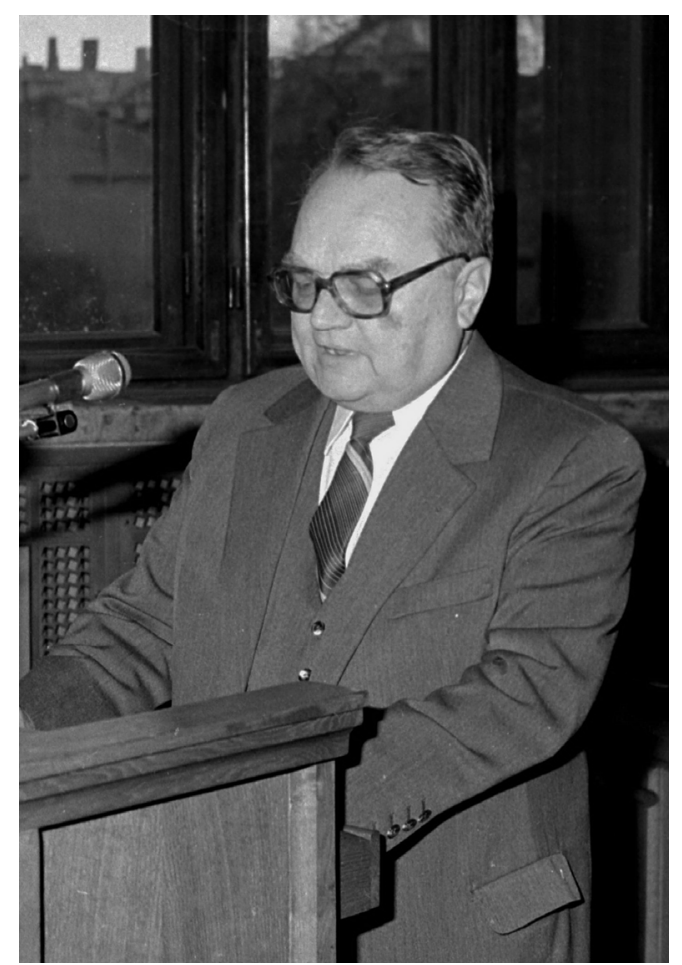

Fig. 8. Professor Jerzy Ryś.

When we consider the very beginning of quantitative metallography in Poland, we must recall Professor Jerzy Ryś (Fig. 8), whose role in introducing quantitative assessments by stereological methods into Polish science is crucial.

At first, his scientific interests focused on the problems of statistical methods for metallurgy and metallurgical issues. In 1960, he defended his doctorral dissertation, which was the first application of a statistical method of multiple correlation in Polish metallurgy. In 1965, in his habilitation (a post-doctoral degree) work Evaluation of the application of quantitative microscopic methods to determine the dispersed phases in steel (Ryś, 1965), stereological methods of measurement were applied for the first time in Polish metallography.

In 1966, Jerzy Ryś held a scientific internship at the University of Erevan (USSR), where he had an opportunity to work with S. A. Saltykov, a world authority in the field of quantitative metallography. Undoubtedly, working with Saltykov inspired the young scientist from Poland and contributed to the strengthening of his scientific interests and desire to disseminate the idea of objective and quantitative analysis of microstructures. The book by S. A. Sałtykov, Stereometric metallography (Saltykov, 1958) influenced his interest in measurements in metallo- graphy. He was aware of how stereological methods can contribute to increasing the efficiency and reliability of analysis; he also knew that precise description of microstructure components makes it possible to detect the relation between them and the mechanical properties of materials.

After returning to Poland, Jerzy Ryś created the Quantitative Metallography Group within the Department of Metallography at AGH University of Science and Technology, which in 1968 was transformed into the Laboratory of Quantitative Metallography of the Department of Metal Science and Heat Treatment, with Jerzy Ryś as manager.

In 1970, the first handbook in Poland on stereological methods was published - Introduction to quantitative metallography (Ryś, 1970).

In the preface, he wrote "...In current metallographic practice, comparative methods are most widely used, which, without being fully quantitative methods, do not allow objective and fully repeatable characteristics of a metal's microstructure. Therefore, comparative methods should be replaced wherever possible by geometric measurement of microstructure parameters, as only quantitative microstructure estimation can find close relationships between the microstructure and the technological parameters of the metal manufacturing process...”. In this small book, Jerzy Ryś briefly presented the crucial methods for quantitative analysis of the microstructure of metals: measurement of volume fraction of microstructure components applying Cavalier's planimetric, linear and point methods; measurement of boundary surfaces separating components of the microstructure; determination of the number of grains; determination of the number of grains per unit area; quantitative evaluation of the expected mean curvature. This small handbook has made a great contribution to the popularization of stereological methods in metallurgy and material science. At the same time, Ryś also elaborated and introduced stereology (as "Quantitative Metallography") as a separate course for students of AGH University of Science and Technology. He lectured until 1992.

Over time, the Laboratory of Quantitative Metallography at AGH University of Science and Technology, led by Jerzy Ryś, became a leading national research centre for the application of statistical methods in metallurgy and quantitative metallography. The scientific activity of the Laboratory consisted of three basic directions:

1. Correlational or variance analysis. Specifically, 
research on the influence of chemical composition on the properties of materials in which the main tool was multiple correlation. Works of this type have contributed greatly to the solution of certain metallurgical problems.

2. Stereological quantitative metallography. This direction mainly included stereological methods for measuring the quantitative characteristics of microstructures of materials.

3. Quantitative metallography. In particular: quantitative dependence of material properties on microstructure; coagulation of dispersive carbide phases in steels; spheroidization of carbides in microstructures of the so-called "grid" and with tiles (perlite); the curvature of grain boundaries and phases; double angles in the structure of grain boundaries; microscopic texture; dispersion phases (globular and platelet).

The next handbook on stereology methods was published in 1983; it was an extensive work on the methods of classical stereology. In 1992, Jerzy Ryś retired, but continues to carry out scientific work. In 1995, he published the book "Stereology in material science". It should be highlighted that even now there are no other handbooks on stereology in Polish, other than Jerzy Ryś handbooks. Obviously, this duty falls on the new generation of stereologists in Poland.

Jerzy Ryś was an unquestioned authority in statistical methods, statistical quality control, quantitative metallography, and stereology. He is widely considered the creator of the Polish school of stereology and quantitative metallography. He was greatly benevolent and willing to help by sharing knowledge with the next generations of students. This is probably why so many young scientists gathered around him with a willingness to cooperate. Nowadays his students work in various scientific centres all over Poland and abroad. His activity stimulated the development of quantitative metallography and stereology in Silesia, Krakow, Warsaw, and Czestochowa University of Technology. His participation in scientific seminars, research consultations, and reviews of doctoral dissertations and postdoctoral fellowships has significantly contributed to the development of academic staff in these centres.

\section{SCIENTIFIC STEREOLOGICAL GROUPS IN POLAND}

Over time, more and more centres have emerged in which the application of stereology in metallography has been taken up and developed. At AGH University of Science and Technology, Jerzy Ryś's group with Kurt Wiencek (Fig. 9), Henryk Adrian, Andrzej Czarski, Kazimierz Satora and Tadeusz Skowronek have developed stereological characterristics and modelling of the coagulation of carbides (Ryś and Wiencek, 1979). In his habilitation dissertation, Kurt Wiencek has addressed the stereology of convex grains (Wiencek, 1996); he has also contributed in subjects such as statistical properties of microstructures of materials, statistical correlations in microstructures, description of microstructure elements using geometric-stochastic models, and quantitative description of the structural processes in materials. Henryk Adrian has conducted research on linear cross-sections of polycrystals (Adrian, 1992). Andrzej Czarski in his $\mathrm{PhD}$ dissertation proposed a new method of quantitative description of the lamellar structure of perlite (Czarski and Ryś, 1987). The problem of coagulation of dispersive carbide phases in steels was the subject of scientific interests of Kurt Wiencek, Kazimierz Satora, and Piotr Matusiewicz (Adrian and Wiencek, 2015, Czarski et al., 2015, Matusiewicz and Czarski, 2013, Skowronek et al., 2004).

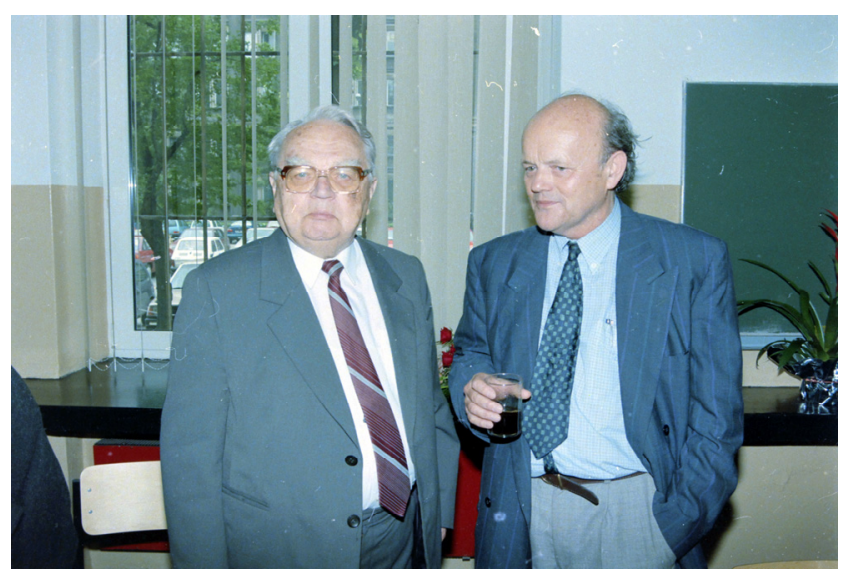

Fig. 9. From the left Prof. Jerzy Ryś and Prof. Kurt Wieneck.

At the Foundry Research Institute, Krzysztof Hübner applied computer image analysis to microstructure analysis of graphite in cast iron (Hübner, 1977).

The mathematical foundations of stereology and image analysis and its application in analysis of rock structures were the domain of Jakub Bodziony and Mariusz Młynarczuk from the Strata Mechanics Research Institute of the Polish Academy of Science. Mariusz Młynarczuk has developed computer image analysis methods in rock structure analysis. He interests in application of advanced image processing including artificial intelligence for rock structure analysis and type of rock identification (Mlynarczuk, 2005, Mlynarczuk et al., 2016, Mlynarczuk and Skiba, 2017, Mlynarczuk and Wierzbicki, 2009). 


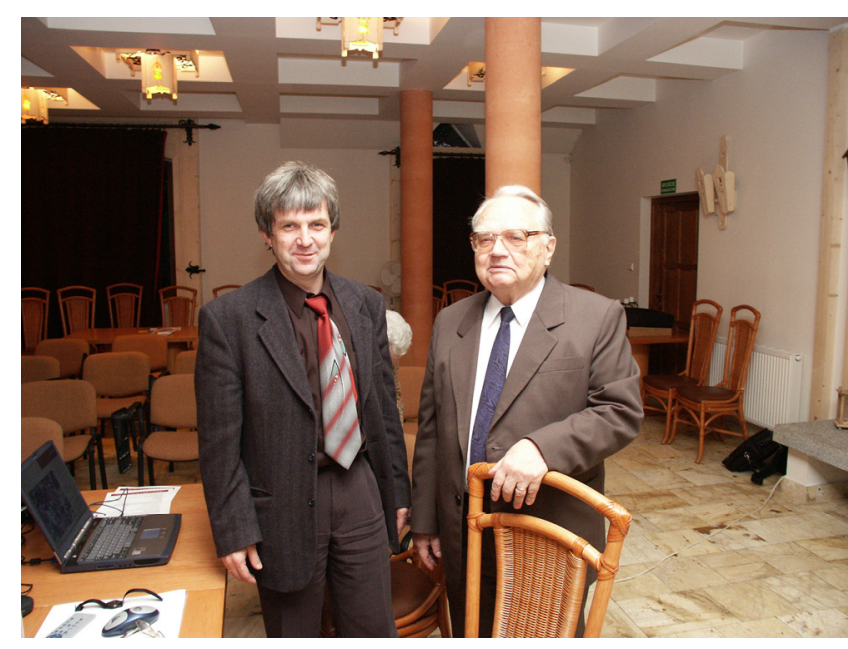

Fig. 10. From the left: Professor Leszek Wojnar and Professor Jerzy Ryś.

At Krakow University of Technology, Leszek Wojnar's group specializes in the application of stereology and methods of image analysis in quantitative metallography, biology, and medicine. Leszek Wojnar systematized the theoretical basis of quantitative fractography, introduced an analysis of overlaps interpreted as secondary cracks, and demonstrated their role in the cracking process (Wojnar, 1990, Wojnar, 1992). He definitely polemicized with stereology guru Professor Ervin E. Underwood on the upper bound of the degree of expansion of the surface from the expansion of the crack profile. The dispute ended with a private letter from Professor Underwood to Leszek Wojnar, in which he wrote, "Our computer simulations have shown that you may be right". Wojnar always pointed to the strong links between stereology and image analysis, even before the Image Analysis and Stereology Journal and The International Society for Stereology and Image Analysis changed their names accordingly. His US-published book entitled Image analysis. Applications in materials engineering (Wojnar, 1999) was the first in the world to describe precisely the algorithms of analysis. In other words, it was something like a cookbook: other items related to image analysis were described as if they were individual vegetables, meat, and seasonings. Through his activities, he contributed to the popularization of computer image analysis in the field of material science, biology and medicine (Gadek et al., 2006, Latala et al., 2010, Latala and Wojnar, 2001) Doctorates of Professor Wojnar developed new methods in their theses for assessing medical images with stereological methods, i.e.: Zbigniew Latała's dissertation (Latała, 2002) concerned the application of computer image analysis in ultrasound examination of the heart. Aneta Gądek-Moszczak developed a new method for quantitative assessment of bone regeneration using the Ilizarov method (Gadek-Moszczak et al., 2015, Gądek, 2005). Dariusz Karpisz proposed a new biometrical method based on X-ray analysis of the frontal sinus shape (Karpisz, 2008).

Quantitative microstructure analysis and industrial applications of stereology have been developed by a large group at Silesian University of Technology with Adolf Maciejny, Jan Cwajna, Janusz Szala, Marian Maliński and Jacek Chrapoński. Jan Cwajna is exploring the topic of theoretical stereology, non-homogeneity quantification, and quantitative fractography (Cwajna, 1994, Cwajna, 2005, Cwajna et al., 1997, Stach et al., 2005a). Image analysis algorithms are the specialty of Janusz Szala, who developed software called Met-Ilo for image processing and analysis (Szala, 2003a; b). Marian Maliński and Jacek Chrapoński deal with computer simulation and stereological relations (Gawdzinska and Malinski, 2005, Maliński and Chrapoński, 1997, Maliński and Chrapoński, 2008). Marian Maliński's handbook: Computer-aided verification of statistical hypotheses (in polish) is a highly valued student guide to statistical issues in research (Maliński, 2004). Nearby, at the University of Silesia, Jan Cybo and Sebastian Stach have worked on fractal and multifractal analysis of surfaces and microstructures (Stach et al., 2005b, Stach et al., 2014).

The stereological community associated with Krzysztof Kurzydłowski at Warsaw University of Technology deals with the application of stereology in the development of quantitative structure-property relationships for various materials, computer simulations of structural changes, and analysis of grain growth processes. In 1995, Kurzydłowski and Brian Ralph published $A$ quantitative description of the microstructure of material (Kurzydłowski and Ralph 1995). PhD students of Krzysztof Kurzydłowski including Janusz Bucki, Krzysztof Rożniatowski inspired by their thesis supervisor developed application of stereological methods for quantitative assessment of materials microstructure in their $\mathrm{PhD}$ thesis. Krzysztof Rożniatowski in habilitation dissertations focused on the issue of inhomogeneity characterization of the structural elements in multiphase materials (Rożniatowski, 2008).

The image analysis and stereology has also been extended to research activities related with modeling of 3D microstructure (Wejrzanowski et al., 2017) and quantitative structure-property relationships (Skibinski et al., 2015, Wejrzanowski et al., 2016) in engineering materials. This domain is mostly explored by newest generation of stereologists at Warsaw University of Technology and in particular by Tomasz Wejrzanowski. 
These three centres in Krakow, Katowice, and Warsaw work in close cooperation, which resulted in the publication of a chapter in the ASTM handbook Quantitative Image Analysis (Wojnar et al., 2004) and a book, Practice of image analysis by Leszek Wojnar, Janusz Szala and Krzysztof Kurzydłowski (Wojnar et al., 2002). This book is appreciated by students for its accessible style and interesting presentation of typical and unusual image analysis problems and examples of solutions.

At Czestochowa Technical University, the group of Stefania Stachurowa and Leopold Jeziorski are investigating the use of stereological methods to describe metal microstructures (Golanski et al., 2017, Lis et al., 1977, Stachura, 1995).

In Lublin at Institute of Agrophysics, Krystyna Konstankiewicz and Henryk Czachor have developed and applied stereological methods to agricultural sciences.

\section{POLISH SOCIETY FOR STEREOLOGY (1988 - )}

The official date of the establishment of the Polish Stereological Society in 1988 was just a formal step that allowed the creation of a space to exchange ideas and experiences related to the easier and more systematic development and use of stereological tools. The Society gathers people with similar interests, thus allowing them to support each other and facilitate an exchange of knowledge between scientific centres in Poland and abroad through simple and natural activities such as the sharing of world literature on stereology and its application. When the world was divided by the Iron Curtain, the exchange of knowledge was a significant problem that is difficult to imagine for the current internet-savvy generation.

In 1988, a group of enthusiasts created a formal space for the exchange of knowledge, experience, new ideas, cooperation in the field of stereology, and its application in materials science, biology, and medicine. Thanks to this initiative, which was launched at the $2^{\text {nd }}$ Conference on Stereology in Materials Science, this idea came to fruition in the autumn of 1988. The first president of the Polish Society for Stereology was Jakub Bodziony. Vice president for the application of stereology in material science was Jerzy Ryś; vice president for the application of stereology in biology and medicine was Edward Waniewski of the Military Medical Academy in Warsaw. The function of secretary was fulfilled by Leszek Wojnar from Krakow University of Technology; the treasurer was Kazimierz Satora from AGH University of Science and Technology. Other members of the Board of Society were Jan Cwajna from Silesian University of Technology, Elżbieta Kaczmarek from the Medical Academy in Poznań, and Jacek Kordek from AGH University of Science and Technology. It is worth emphasizing that Kazimierz Satora (as treasurer) and Leszek Wojnar are still active members of the board.

The goal of the Society, as defined in its statute, is supporting, developing, and popularizing scientific, technical, educational and activities in field of stereology, as a discipline of science that deals with the study and processing of information derived from images. Since the very first meeting, the workshops and conferences organized by the Society have been very important events not only for all members, but also for others dealing with stereology and its applications. The STERMAT series of Conferences (STEReology in MATerials) that is held usually every 4 years is the most important event for the Society as it allows international participants to present and dissect actual achievements. The last was held in 2016. STERMAT was begun in 1983 as a Conference of Stereology in Material Science. Since 1990, the official language of the conference has been English and its name was changed in response to a suggestion by Jean-Luis Chermant. The STERMAT conference hosts participants from all over the world, including Ervine Underwood, Jean Serra, Ivan Saxl, Hans Jørgen G. Gundersen, Dominique Jeulin, Jean-Louis Chermant, Victor Benes, Brian Ralph, George Vander Voort and many, many other international scholars (Figs. 11-13). The last Conference of STERMAT series was held in 2016, in Białka Tatrzańska and gave a chance to exchange the know-ledge and experiences from application of stereology in material science field the numerous participants from Poland, Czech Republic, Slovakia, Germany, United's States and even from Brazil.

Another very important activity of the Society is the Autumn Workshops on Stereology and Image Analysis that are traditionally held almost every year in Zakopane (Fig. 14). At these workshops, young scientists give presentations on current research, doctoral thesis topics, or independent attempts to deal with the issues associated with stereology and image analysis. It is also a great opportunity to discuss in a friendly atmosphere problems encountered during dissertations with older, more experienced colleagues. 


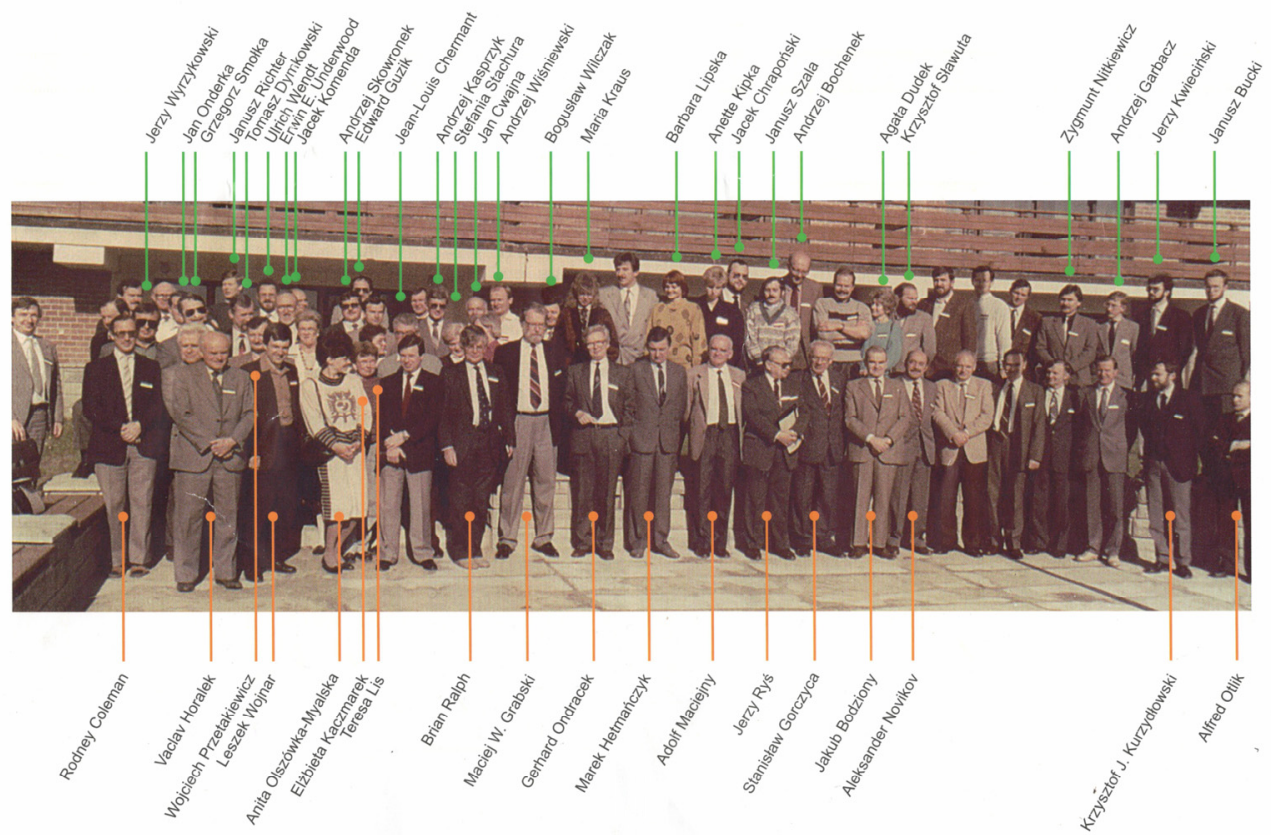

Fig. 11. Participants of Conference: Stereology in Materials Science - STERMAT 90" Szczyrk 1990.

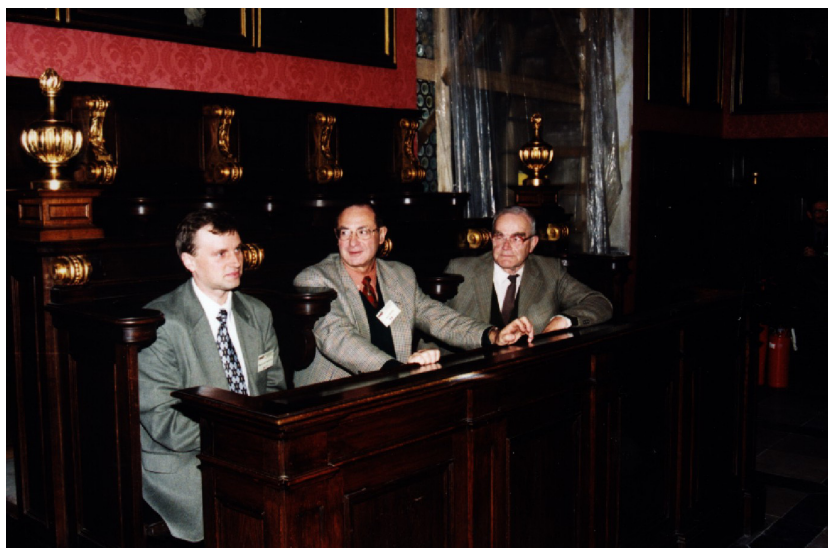

Fig. 12. During opening ceremony Stermat2000 in medieval Collegium Maius, from the left: Mariusz Młynarczuk, Jean Serra, Jakub Bodziony.

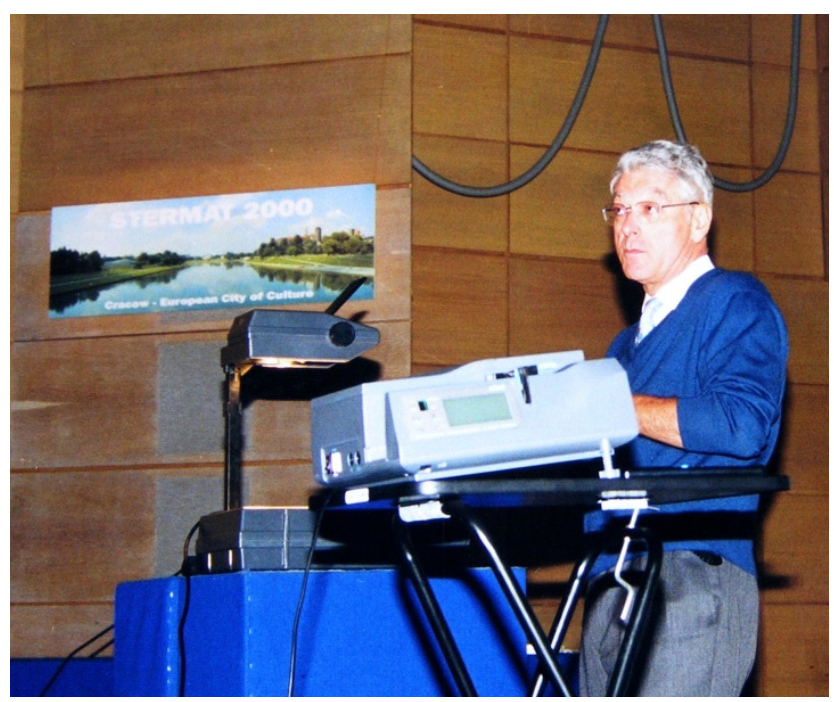

Fig. 13. Jean-Luis Chermant, Stermat 2000.

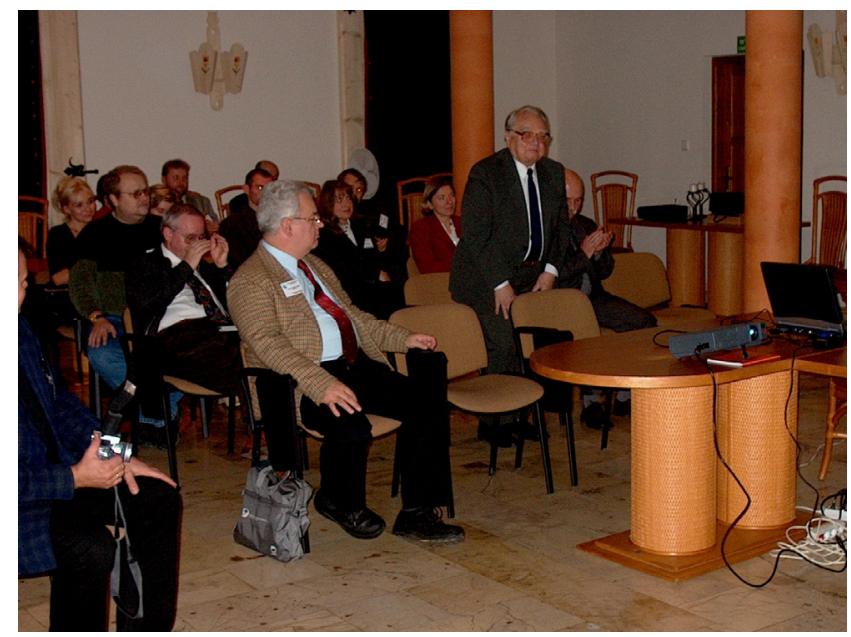

Fig. 14. Autumn Workshop in Zakopane, 2002 (first row - George Vander Voort, Jerzy Ryś).

Last Workshop devoted Stereology an Image Analysis was held in Białka Tatrzańska in 19-21th of April 2015. Because the workshop took place in spring, the name was changed to Spring Workshop, but this event is obviously continuation of the Autumn Workshop. During 2 days participants had an opportunity to listen the lectures of Leszek Wojnar on "Principles of stereology" (Figs. 15 and 17) and Janusz Szala on "Principles of Image Analysis" (Fig. 16). Jacek Chrapoński in his lecture introduced participants into issues of modern stereology: "Selected methods of modern stereology". Marian Maliński presented lecture "On (in) correct analysis of test results". 


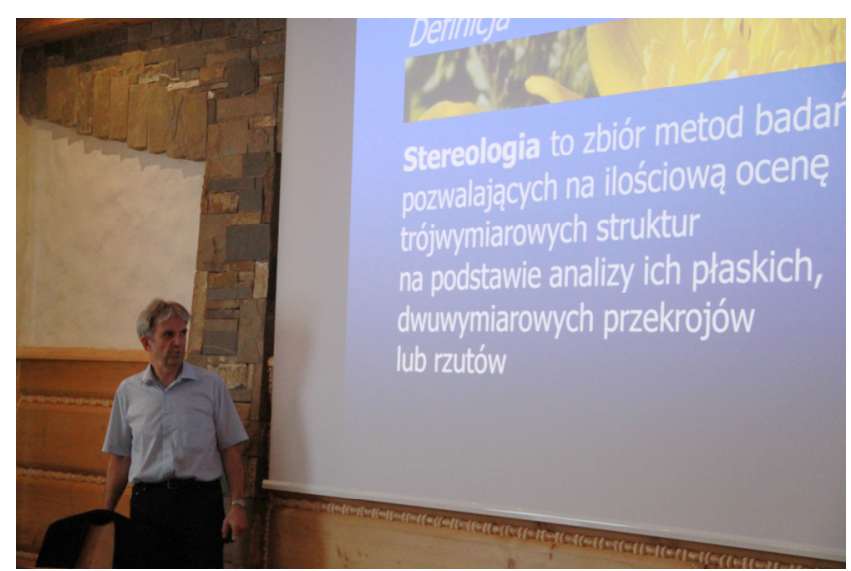

Fig. 15. Leszek Wojnar on Spring Workshop on Stereology and Image Analysis, 2015.

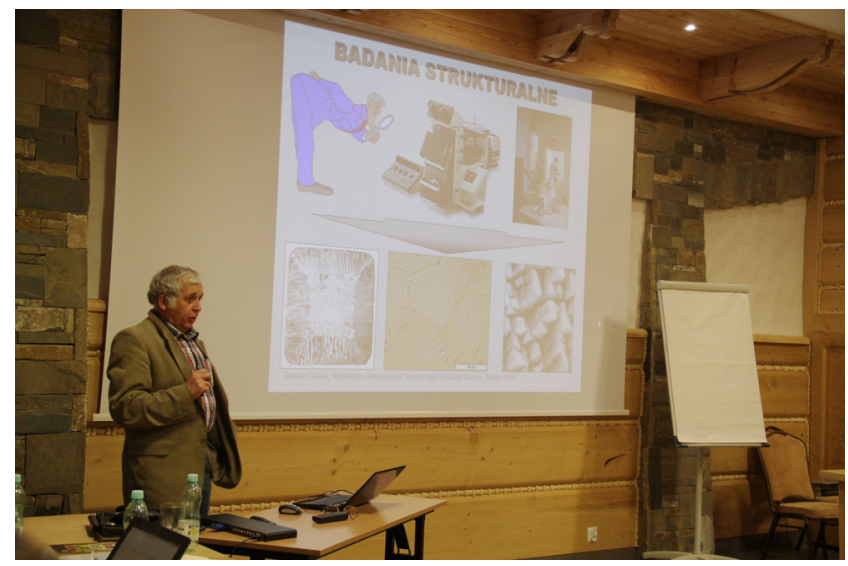

Fig. 16. Janusz Szala on Spring Workshop on Stereology and Image Analysis, 2015.

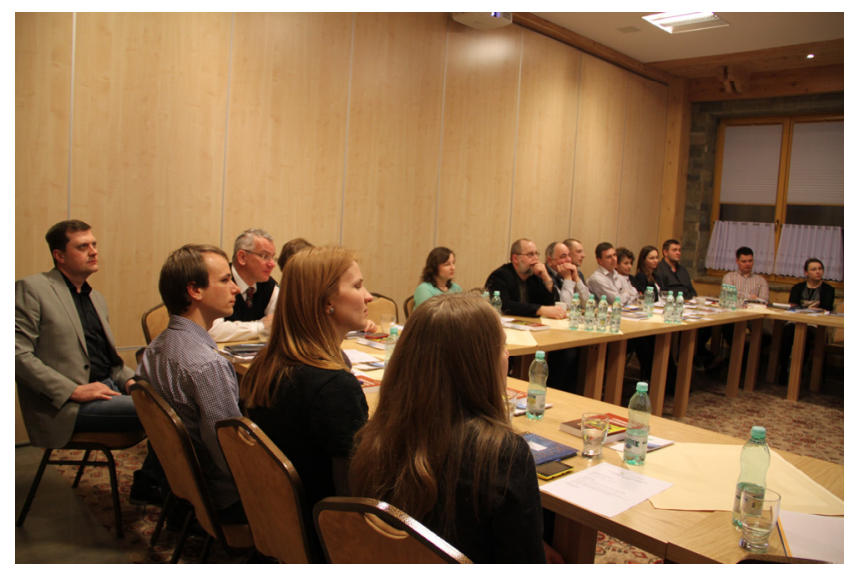

Fig. 17. Participants of the Spring Workshops on Stereology and Image Analysis, 2015.

Polish Society for Stereology activists for the promotion of stereology include patronage of training for industrial customers, held by DCOSBIM Technical-Training Office.

\section{CONCLUSIONS}

This brief review of the history of stereology in Poland has shown that the first attempts to develop quantitative descriptions of objects in images date back to the 1930s. Over the years, many prominent scientists have contributed to the development and dissemination of stereological methods.

Nowadays, when tools for computer image analysis allow fully automated measurements, we might notice a decrease in awareness of the methods used, which might in turn lead to improper use. Another problem resulting from insufficient knowledge of stereology is the difficulty in solving non-standard issues that do not have a ready-made analysis algorithm in software.

Some say that stereology is an outdated science that is no longer used because there is no need to describe objects and the structure of materials on the basis of cross-sections or projections, because computed microtomography is now widely applied for visualization of the internal structure of objects,.

However, even modern techniques such as computed microtomography have their limitations due to technical constraints such as the physical phenomena that allow images of the study object to be created, the size of the examined object, the spatial resolution obtained, and the relatively high cost of a single test.

In routine quality control tests of manufactured materials or components, microscopic methods are still used to provide images of flat sections of analysed objects. Computed microtomography is an excellent way to obtain three-dimensional images of the real inner structure of tested objects. However, Xray images show objects that are quite significantly different in terms of X-ray absorption coefficient. If a test material consists of elements with similar coefficients, their detection and analysis can be very difficult or practically impossible. It is possible to obtain images with a voxel size less than micrometer, but 1 nanometer is still impossible; for accurate material analysis this is not sufficient and certainly not a substitute for SEM or TEM studies.

Despite the long history of stereology, the authors are of the opinion that it has not aged; therefore, the need to popularize it and its wide application is still valid.

\section{REFERENCES}

Adrian H (1992). Statistical characteristics of selected polyhedra. Acta Stereologica 11:143-55.

Adrian H, Wiencek K (2015). Austenite grain size esti- 
mation in structural steels by linear section method. Archives of Metallurgy and Materials 60:2463-9.

Bodziony J (1965a). O pewnych wskaźnikach charakteryzujących geometryczną strukturę skał. Bulletin of the Polish Academy of Sciences 9:469.

Bodziony J (1965b). Definicja wielkości ziarn oparta na pojęciu całkowitej krzywizny średniej. Bulletin of the Polish Academy of Sciences, 10.

Bodziony J, Hübner K (1987). Hugo steinhaus - an unknown stereologist? Acta Stereologica 6:69-78.

Bodziony J (1993). Stereology in geosciences: Achivements, difficulties and limitations. Acta Stereologica 12:21122.

Cwajna J (1994). Quantitative structural criteria of steel quality control. Acta Stereologica 13:409.

Cwajna J, Richter J, Szala J (1997). Quantitative mettallography and fractography of modern tool alloys. Proc Q-Mat'97, International Conference on the Quantitative Description of Materials Microstructure, Warsaw, Poland: 125.

Cwajna J (2005). Complex procedures of quantitative description of materials microstructure. In: Kurzydlowski KJ, Pakiela Z (eds). Bulk and graded nanometals, 28796.

Czarski A, Ryś J (1987). Stereological relationships for lamellar structure. Acta Stereologica 6:567-72.

Czarski A, Skowronek T, Matusiewicz P (2015). Stability of a lamellar structure - effect of the true interlamellar spacing on the durability of a pearlite colony. Archives of Metallurgy and Materials 60:2499-503.

Czochralski J (1935). Metoda ilościowego oznaczenia wtrąceń niemetalicznych (method of quantitative determinatrion of non-metallic inclusions; in polish). Wiadomości Instytutu Metalurgii i Metaloznawstwa Politechniki Warszawskiej 2:34-6.

Czochralski J, Sznuk W (1936). Próby objektywnego określania zawartości wtrąceń niemetalicznych na szlifie, (attempts at an objective determination of contenyts of non-metallic inclusions on microsections; in polish). Wiadomości Instytutu Metalurgii i Metaloznawstwa Politechniki Warszwawskiej 3:5-6.

Gadek-Moszczak A, Pietraszek J, Jasiewicz B, Sikorska S, Wojnar L (2015). The bootstrap approach to the comparison of two methods applied to the evaluation of the growth index in the analysis of the digital x-ray image of a bone regenerate. Stud Comput Intell 572: $127-36$.

Gadek A, Kuciel S, Wojnar L, Dziadur W (2006). Application of computer-aided analysis of an image for assessment of reinforced polymers structures. Polimery 51:206-11.

Gawdzinska K, Malinski M (2005). Study of reinforcement elements distribution exemplified by composite with alsi11 matrix and carbon reinforcement. Metalurgija $44: 45-8$.
Gądek A (2005). Computer image analysis of bone regenerate in the Ilizarov method. Kraków: Fotobit.

Golanski G, Jasak J, Zielinski A, Kolan C, Urzynicok M, Wieczorek P (2017). Quantitative analysis of stability of $9 \% \mathrm{Cr}$ steel microstructure after long-term ageing. Archives of Metallurgy and Materials 62:263-71.

Hübner K (1977). Quantitative characteristics of the shape of graphite precipitates in nodular cast iron. Przegląd Odlewnictwa, 3.

Kac M (1974). Hugo Steinhaus -a reminiscence and a tribute. The American Mathematical Monthly Mathematical Association of America 81:572-81.

Karpisz D (2008). The use of frontal sinus radiographs image analysis as a base of identifying unknown persons. $\mathrm{PhD}$ thesis, Cracow University of Technology, Kraków.

Kraj W (1986). On the spatial orientation of the surfaces of discontinuities in a material. Bulletin of the Polish Academy of Sciences 34:171-8.

Kurzydłowski KJ, Ralph B (1995). The quantitative description of the microstructure of materials. Florida: CRC Press, Boca Ration.

Latala Z, Wojnar L (2001). Computer-aided versus manual grain size assessment in a single phase material. Materials Characterization 46:227-33.

Latala Z, Tabor Z, Wojnar L (2010). Microtomography of whole trabecular bodies. Osteoporosis Int 21:210-1.

Latała Z (2002). Zastosowanie komputerowej analizy obrazu ultrasonograficznego do badania serca. $\mathrm{PhD}$ thesis, Cracow University of Technology, Kraków.

Lis J, Jeziorski L, Lis A (1977). Structural morphology and mechanical-properties of heat-treated steels. Neue Hutte 22:446-51.

Maliński M, Chrapoński J (1997). 3D modelling of polycrystalline grain structure, parts I and II. Q-Mat'97, International Conference on the Quantitative Description of Materials Structure 7:433.

Maliński M (2004). Weryfikacja hipotez statystycznych wspomagana komputerowo. Gliwice: Wydawnictwo Politechniki Śląskiej.

Maliński M, Chrapoński J (2008). Application of point sampled intercept method for quantitative description of anisotropic structures. Materials Science Forum 567-568:157-60.

Matusiewicz P, Czarski A (2013). Spatial distribution of cementite particles in $\mathrm{Fe}-0.67 \% \mathrm{C}$ steel. Archives of Metallurgy and Materials 58:631-4.

Mlynarczuk M (2005). Application of image analysis and mathematical morphology in petrography. Przegląd Elektrotechniczny 81:20-5.

Mlynarczuk M, Wierzbicki M (2009). Stereological and profilometry methods in detection of structural deformations in coal samples collected from the rock and outburst zone in the "zofiowka" colliery. Arch Min Sci 54:189-201.

Mlynarczuk M, Habrat M, Skoczylas N (2016). The 
application of the automatic search for visually similar geological layers in a borehole in introscopic camera recordings. Measurement 85:142-51.

Mlynarczuk M, Skiba M (2017). The application of artificial intelligence for the identification of the maceral groups and mineral components of coal. Comput Geosci-Uk 103:133-41.

Ratajczak T (2005). Mikroskopowe pomiary ilościowe skał - rys historyczny. Polskie Towarzystwo Mineralogiczne, Prace Specjalne 27:9-20.

Rożniatowski K (2008). Metody charakteryzowania niejednorodności rozmieszczenia elementów strukturalnych w materiałach wielofazowych, vol. 22. Warszawa: Politechnika Warszawska.

Ryś J (1965). Ocena stosowania ilościowych metod mikroskopowych do określania faz dyspersyjnych w stali. Kraków: AGH.

Ryś J (1970). Wstęp do metalografii ilościowej. Katowice: Wydawnictwo Śląsk.

Ryś J, Wiencek K (1979). Koagulacja faz w stopach. Katowice: Wydawnictwo Śląsk.

Saltykov SA (1958). Stereometric metallography. Moscow: Metallurgizdat.

Skibinski J, Cwieka K, Kowalkowski T, Wysocki B, Wejrzanowski T, Kurzydlowski KJ (2015). The influence of pore size variation on the pressure drop in open-cell foams. Materials \& Design 87:650-5.

Skowronek T, Ratuszek W, Chrusciel K, Czarski A, Satora K, Wiencek K (2004). Spheroidization of cementite in pearlite. Archives of Metallurgy and Materials 49:96171.

Stach S, Cwajna J, Roskosz S, Cybo J (2005a). Multifractal description of fracture morphology: Quasi-3d analysis of fracture surface. Materials Science-Poland 23:56775.

Stach S, Cybo J, Cwajna J, Roskosz S (2005b). Multifractal description of fracture morphology. Full 3d analysis of a fracture surface. Materials Science-Poland 23:577-84.

Stach S, Lamaza A, Wrobel Z (2014). 3d image multifractal analysis and pore detection on a stereometric measurement file of a ceramic coating. Journal of the European Ceramic Society 34:3427-32.

Stachura S (1995). A comparison of the fracture-behavior of $36 \mathrm{CrNiMo} 4$ steel from industrial heats differing in sulfide type. Journal of Materials Processing Technology 53:781-97.

Steinhaus H (1930). Zur praxis der rektifikation und zum langenbegriff. Berichte uber die Verhandlungen der
Sachsischen Akademie der Wissenschaften zu Leipzig, MAthematisch-Physische Klasse 88:120-30.

Steinhaus H (1932). W sprawie mierzenia długości linij krzywych płaskich. Polski Przegląd Kartograficzny 10:145-53.

Steinhaus H (1938). O optycznej lokalizacji przedmiotów i pewnym jej zastosowaniu. Archiwum Towarzystwa Naukowego we Lwowie, 9.

Steinhaus H (1947a). O wskaźniku ukształcenia pionowego. Przegląd Geograficzny 21:113-5.

Steinhaus H (1947b). O wskaźniku zgęszczenia i rozproszenia. Przegląd Geograficzny 21:109-11.

Steinhaus H (1973). Autobiografia. Roczniki Polskiego Towarzystwa Matematycznego, Seria II: Wiadomości Matematyczne XVII:3-11.

Szala J (2003a). Komputerowa analiza obrazu w metalografii ilościowej. Informatyka w Technologii Materiałów 3:41-57.

Szala J (2003b). Zastosowanie metod komputerowej analizy obrazu do ilościowej oceny struktury materiałów, vol. 61.

Śmiałowski M (1936). O nowym mikrofotometrze rejestrującym i jego zastosowaniu do ilościowego oznaczenia wtrąceń niemetalicznych Wiadomości Instytutu Metaloznawstwa 3:45-55.

Wejrzanowski T, Grybczuk M, Chmielewski M, Pietrzak K, Kurzydlowski KJ, Strojny-Nedza A (2016). Thermal conductivity of metal-graphene composites. Materials \& Design 99:163-73.

Wejrzanowski T, JHaj Ibrahim S, Skibinski J, Cwieka K, Kurzydłowski KJ (2017). Appropriate models for simulating open-porous materials. Image Analysis and Stereology 36:107-12.

Wiencek K (1996). Stereologia zbioru ziarn wypukłych i jej zastosowanie w metalografii. Habilitation thesis, AGH University of Science and Technology, Kraków.

Wojnar L (1990). Fraktografia ilościowa: Podstawy i komputerowe wspomaganie badań, vol. 72. Kraków: Cracow University of Technology.

Wojnar L (1992). Unbiased estimation of fracture surface area. Acta Stereologica 11:651-6.

Wojnar L (1999). Image analysis: Applications in materials engineering. USA: CRC Press Boca Raton.

Wojnar L, Kurzydlowski KJ, Szala J (2002). Praktyka analizy obrazu. Kraków: Polish Society for Stereology.

Wojnar L, Kurzydłowski KJ, Szala J (2004). Quantitative image analysis. ASM handbook Metallography and Microstructures (ASM International), 403-27. 